\title{
Marek Hendrykowski Uwagi o aktorstwie w filmach Andrzeja Wajdy
}

\begin{abstract}
Hendrykowski Marek, Uwagi o aktorstwie w filmach Andrzeja Wajdy [Remarks on acting in Andrzej Wajda's films]. „Przestrzenie Teorii” 27. Poznań 2017, Adam Mickiewicz University Press, pp. 47-58. ISSN 1644-6763. DOI 10.14746/pt.2017.27.6.

The article is a synthetic look at Andrzej Wajda's films in terms the context of acting and actors' participation. As a director Wajda never created a separate 'school' of film acting; nevertheless, he still made a huge creative contribution on a national and global scale, including tens, if not hundreds, of unforgettable performances from actors.
\end{abstract}

\section{Wprowadzenie bez tezy}

Ogromna liczba publikacji, jakie poświęcono pamiętnej kreacji Zbigniewa Cybulskiego w Popiele $i$ diamencie, miała ten uboczny skutek, że na długie lata przysypała wszelkie inne ewentualne tematy dotyczące aktora i aktorstwa w filmach Andrzeja Wajdy. On sam zresztą sakralizował poniekąd ten mit, realizując tuż po tragicznej śmierci Cybulskiego Wszystko na sprzedaz (realizacja 1968, premiera 28 stycznia 1969 roku). Hasło „Wajda i aktorstwo” było od tego momentu równoznaczne z hasłem „Wajda i Cybulski”. Taki stan rzeczy, z niewielkimi tylko modyfikacjami, trwa aż po dzień dzisiejszy. „Buntownik z chlebakiem” wciąż rzuca długi cień.

Choć tak się wtedy sprawy w sferze zbiorowej świadomości ułożyły i momentalne skojarzenie Wajda - Cybulski pozostaje żywe do dzisiaj, nie znaczy to wcale, iż tak już zawsze być musi. Gdy popatrzeć szerzej na całokształt jego twórczości reżyserskiej, relacja Wajda - aktorzy zawiera $\mathrm{w}$ sobie, oprócz wielkiej roli Zbyszka w Popiele $i$ diamencie, niezwykle bogaty i zróżnicowany repertuar artystycznych dokonań. Właściwie w niemal każdym jego kolejnym filmie daje o sobie znać co najmniej jedno odkrycie aktorskie (niegdyś Krystyna Janda, Agnieszka w Człowieku $z$ marmuru, a w ostatnim filmie Bronka Zamachowska jako Nika Strzemińska w Powidokach) - jeśli nie absolutny debiut, to w każdym razie pamiętna rola, od której zaczyna się czyjś nowy rozdział w karierze. Nie chodzi tylko o pamiętne debiuty i pierwsze wielkie kreacje filmowe (Łomnickiego, Cybulskiego, Radziwiłowicza, Jandy i innych), lecz o przełamy- 
wanie bądź wzbogacanie dotychczasowego emploi przez wykonawców już wypróbowanych, którzy pod okiem Wajdy odnajdują swoje nowe aktorskie wcielenia.

\section{Początki, czyli reżyser w poszukiwaniu aktora}

Nie sposób twierdzić, iż aktorstwo jako problem i zadanie reżyserskie stało się ważne dla młodego absolwenta PWSF już podczas studiów w Łodzi (1949-1953), gdzie profesjonalnie prowadzone zajęcia praktyczne z aktorem dopiero raczkowały. Prawdę powiedziawszy, pod względem warsztatu reżyserskiego dwudziestokilkuletni adept umiał i potrafił jeszcze wtedy niewiele. Nic dziwnego, że gra aktorów w paru nakręconych przez Wajdę etiudach pozostawia, delikatnie mówiąc, wiele do życzenia. Dominuje bezduszna sztampa. Wykonawcy są sztywni, pozbawieni indywidualnego wyrazu, poprawni i schematyczni. W ich bezbarwnej, niezapadającej w pamięć grze brakuje nerwu i wewnętrznego rytmu. Postaci robią wrażenie „papierowych”, są jednowymiarowe i od początku do końca przewidywalne. Co gorsza, początkujący reżyser - pracując z aktorami na planie filmowym - nie potrafił z nich wydobyć nawet minimum aktorskiej synergii.

Coś ważnego wydarzyło się w tej materii dopiero po studiach reżyserskich na Targowej. Zupełnie nieudaną etiudę fabularną Zły chłopiec (1951) od Pokolenia (1954) dzielą zaledwie trzy lata i - przepaść poziomu gry aktorskiej. Odkrycie doniosłości fenomenu aktorstwa filmowego nastąpiło u Wajdy w momencie, gdy spotkał na swojej drodze kilku młodych, niezwykle utalentowanych aktorów: Tadeusza Łomnickiego (rocznik 1927), Tadeusza Janczara (równolatka Wajdy, rocznik 1926), Zbigniewa Cybulskiego (rocznik 1927) - trójka ta zagra już w Pokoleniu oraz Bogumiła Kobielę (1931), który niebawem porywająco wcieli się w Drewnowskiego w Popiele $i$ diamencie. Wszyscy należą do tego samego pokolenia co Andrzej Wajda, ale w tym, co miało ich połączyć, najważniejsza okazała się jednocząca ich wspólnota twórczych poszukiwań wspólnota ściśle związana nie ze sceną, lecz z wielkim ekranem.

Neorealizm i aktorstwo neorealistyczne wywarło przemożny wpływ na koncepcję aktorstwa filmowego, ku jakiej się Wajda skłaniał i jaką konsekwentnie potem realizował. Typaż, będący ideałem aktorstwa socrealistycznego, dość szybko przestał być horyzontem jego reżyserskich ambicji. Alternatywę dostrzegł w modelu naturalności gry aktorskiej preferowanym w filmach Viscontiego, Rosselliniego, De Siki, De San- 
tisa ${ }^{1}$. Styl ten, organicznie powiązany z admiracją dla naturalnych scenerii, czarno-białą stylistyką zdjęć i werystycznym obrazem świata przedstawionego, był w Polsce doskonale znany, podobnie jak - szeroko wówczas praktykowana przez Włochów - idea, by zatrudniać jako aktorów niezawodowców.

Z tym ostatnim trendem był jednak niejaki problem. Nie mając w tamtym okresie żadnych szans na angażowanie zdolnych amatorów (wyjątek od reguły stanowili jedynie: Roman Polański w Pokoleniu, Emil Karewicz - Mądry w Kanale i Adam Pawlikowski jako Andrzej Kossecki w Popiele $i$ diamencie), postawił na swoich rówieśników, niedawnych absolwentów szkół aktorskich.

Byli wśród nich nie tylko: Łomnicki, Janczar, Cybulski i Kobiela, ale także: Barbara Krafftówna, Władysław Sheybal (oboje słuchacze Studia Dramatycznego Iwo Galla przy Starym Teatrze w Krakowie), Ryszard Kotys, Stanisław Mikulski i in. Owszem, tyle że starał się pracować z nimi inaczej (umiejętnie unikając zwłaszcza warsztatowej rutyny) i reżyserować ich udział w odmienny niż dotąd w polskim filmie sposób. A to oznaczało konsekwentne postawienie na naturalność aktorskiego behavioru i eliminowanie nalotu - uchodzącej za sztukę - wyuczonej w akademiach „teatralności”. „Jeżeli był »amatorem« - powie po latach Wajda, wspominając fenomen aktorstwa Cybulskiego, krytykowany przez zawodowców - to amatorem w stosunku do tych aktorów, którzy uprawiali wtedy w polskim kinie nieco teatralny, przedwojenny styl gry"2.

Nolens volens, trzeba było wypracować własną, indywidualną metodę. Droga do tego prowadziła poprzez wykorzystanie i zaadaptowanie klasycznych już wtedy doświadczeń neorealistów. Nie kopiując jednak ich stylu, należało poszukać czegoś nowego. Patent Wajdy i jego sposób reżyserowania udziału wykonawców, podobnie jak u Munka, stanowiły dłuższe, rozbudowane dramaturgicznie epizody. W opracowaniach tych daje o sobie po raz pierwszy znać kunszt i reżyserski pazur młodego Wajdy.

Ich złożona kompozycja, siłą rzeczy, musiała objąć umiejętną, przemyślaną w najdrobniejszych szczegółach, aranżację udziału aktorów. Styl gry aktorskiej jednoczył się z kompozycją. Na plan pierwszy wyszła kwestia podziałów i segmentacji filmowego materiału, a wraz z nią rytm gry, rytm zdjęć i rytm montażu, w którym cząstka zawiera w sobie świadomość całości, a całość organizuje i łączy w jedno poszczególne ekranowe

1 Z ówczesnych zapisków reżysera wynika, iż poza kinem włoskim tego typu efekt dostrzegał Wajda w filmach: Carola Reeda (Niepotrzebni moga odejść), Akiry Kurosawy (Pijany anioł, Rashomon) i swego ulubionego reżysera, Luisa Buñuela (Zapomniani).

2 A. Wajda, Fenomen Cybulskiego, [w:] W. Zdort, Cybulski na planie „Popiołu $i$ diamentu”, Łódź 1997, s. 89. 
elementy. Na razie jeszcze - tylko fragmentarycznie, w ramach pojedynczych scen, bo organiczną pełnię wyrazu całości lata później przyniesie pod tym względem dopiero Wesele (1972).

Powróćmy jednak do zawodowych początków młodego filmowca. Pierwsze reżyserskie koty za płoty poniekąd zapowiadały i przepowiadały w jego przypadku dzieła znacznie późniejsze. Majstersztykiem inscenizacyjnym reżysera w debiutanckim Pokoleniu okazała się pamiętna sekwencja porwania niemieckiej ciężarówki. Ta sekwencja to jakby oddzielny film w innym filmie! Wyłom dokonany w panującej wtedy estetyce. $\mathrm{Na}$ trzystu metrach taśmy udało się Wajdzie osiągnać kapitalny efekt reżysersko-aktorski w formie, która w niezmiernie sugestywny, by nie powiedzieć - porywający sposób kojarzy w sobie wartości wykonawcze czerpane $\mathrm{z}$ aktorstwa zespołowego (grupa młodych konspiratorów) z indywidualnym popisem Tadeusza Janczara w roli Jasia Krone.

Nadal istotny problem do rozwiązania stanowiło przy tym uzyskanie efektu naturalności aktorskich reakcji i zachowań. Nie jest do końca prawdą, że pierwszą udaną próbą „pisania” sceny na planie zdjęciowym było w przypadku Andrzeja Wajdy dopiero Wszystko na sprzedaż (1968). Robił to już z powodzeniem kilkanaście lat wcześniej, ilekroć zachodziła taka konieczność i orientował się, że aktorzy, z którymi pracuje, są zdolni unieść ciężar i ryzyko tego stylu pracy i wykreować wspólnie z reżyserem scenę, której kształt jeszcze nie istnieje lub ma jedynie ogólne zarysy.

Nieistotne $\mathrm{w}$ tym momencie, czy wykonawcy byli zawodowcami, czy nie. I nie chodzi tu o prosty pogłos neorealizmu, który w tym przypadku mało tłumaczy, lecz o coś więcej. Zdolność do tego typu gry i umiejętność odnajdywania się w niej sprawiała, że w wielu filmach Wajdy pojawiają się aktorzy nieprofesjonalni (wspomniany casus Romana Polańskiego i Adama Pawlikowskiego, ale nie tylko) wraz z okazjonalnymi epizodystami. Ci ostatni, nad wyraz pomysłowo przez niego wykorzystywani, wnoszą do danego utworu określony pozafilmowy kontekst (przykładowo: Krzysztof Komeda w Niewinnych czarodziejach i Popiołach, Irena Dziedzic w Polowaniu na muchy, Bohdan Tomaszewski i góral z Bukowiny Józef Pitorak jako arcybiskup w Krajobrazie po bitwie, głos Czesława Niemena jako Chochoła w Weselu, Jarosław Iwaszkiewicz w prologu Panien $z$ Wilka, Franciszek Starowieyski jako Jacques-Louis David w Dantonie, Jerzy Grzegorzewski jako Jan Matejko w $Z$ biegiem lat, $z$ biegiem dni... i in.).

O związkach między aktorstwem teatralnym a filmowym w twórczości Andrzeja Wajdy będzie jeszcze mowa w dalszej części rozważań. Autorska świadomość tego związku daje o sobie znać już w wypowiedzi reżysera udzielonej w 1962 roku Stanisławowi Janickiemu: 
Teatr [...] daje tę wspaniałą możliwość bliskiego kontaktu z aktorem i uczy reżysera filmowego rzetelnej współpracy z nim. W teatrze można od aktora więcej wymagać, a i on więcej daje reżyserowi i przedstawieniu. [...] W filmie natomiast nie stawia mu się tak wielkich wymagań. Reżyser filmowy posiada ponadto cały arsenał środków, którymi może „obejść” aktora, podporządkować go bezwzględnie swojej woli. Nie znaczy to oczywiście, że pomniejszam rolę aktora w filmie ${ }^{3}$.

Od czasów Popiołu $i$ diamentu do legendy przeszedł specyficzny styl pracy Wajdy z aktorem. Reżyser opisał go w tamtym okresie następująco:

Aktor wyraża główne myśli utworu. Próby poszczególnych scen zaczynam zawsze od prób z aktorami. Dopiero kiedy wiem, jak one zostaną zagrane, zastanawiam się, jak należy je sfotografować. Podczas pierwszych prób sytuacyjnych pozostawiam aktorowi całkowitą swobodę. Czekam na jego propozycje. Bo przecież aktor jest najbliższy postaci, ma najwięcej o niej do powiedzenia ${ }^{4}$.

Cytowana relacja znajduje pełne potwierdzenie w słowach aktora pracującego z reżyserem. Zbigniew Cybulski w rozmowie ze Stanisławem Janickim opisuje ich współpracę następująco:

Wajda bardzo liczy na aktora. Ma on zresztą niespotykaną umiejętność współpracy z nim. Wajda podpatruje właściwości aktora i wykorzystuje je potem w filmie, czy w spektaklu teatralnym. [...] Reżyser, który umie rozmawiać, jest dla mnie bogiem. Takim reżyserem jest Andrzej Wajda, dla którego żywię kult. Zresztą z nim najczęściej pracowałem i dlatego o nim mogę najwięcej powiedzieć. Wajda rozmawiał ze mną nie jak z aktorem, od którego będzie czegoś wymagał, na którym będzie coś budował. Wajda ma szaloną wyobraźnię, nie ma natomiast tego, co niektórzy nazywają „koncepcją reżysera” dotyczącą postaci. Wajda nie mówi - „staniesz tu, potem wyobraź sobie, że to a to się stało, zareagujesz na to" itd. Nie ma tego straszliwego szkolarstwa, tej scholastyki. O Maćku mówiliśmy zawsze w trzeciej osobie, „per on”. W wyniku tych rozmów powstała jakaś wizja tej postaci ${ }^{5}$.

Opisana strategia obsadzania i prowadzenia aktorów przeradza się w coś ogólniejszego, a mianowicie w pewien indywidualny styl inscenizacji rzutujący na charakter całego filmu. Za każdym razem reżyseria w wydaniu Wajdy i jego sposób pracy z wykonawcami polega nie na autorytatywnym dyktowaniu i przesądzaniu z góry, jak ich udział ma wyglądać, lecz na aranżacji puli możliwości - na zaprojektowaniu i wytworzeniu pola działania, które następnie, mniej lub

${ }^{3}$ Andrzej Wajda w rozmowie ze Stanisławem Janickim, [w:] S. Janicki, Polscy twórcy filmowi o sobie, Warszawa 1962, s. 85-86.

4 Tamże, s. 86.

5 Zbigniew Cybulski w rozmowie ze Stanisławem Janickim, [w:] S. Janicki, Polscy twórcy filmowi o sobie, Warszawa 1962, s. 112 i 115. 
bardziej swobodnie, w zależności od przydzielonego zadania, wypełniają oni sobą i swoją grą.

Mając na uwadze ten charakterystyczny aspekt aktorstwa filmowego $\mathrm{u}$ Wajdy, wymienia się zazwyczaj scenę z płonącymi kieliszkami, wymyśloną i wykreowaną przez Zbyszka Cybulskiego na planie Popiołu $i$ diamentu (1958). Nie odbierając należnego tej wspaniałej kreacji uznania, chciałbym jednak zwrócić uwagę na to, że o wiele większy rozmach i frapujący wyraz improwizacja aktorska Cybulskiego osiąga w finałowej sekwencji umierania na śmietnisku. Fascynujący dramatyzm ekranowego agonu stanowi tu wypadkową miejsca (podmiejskie śmietnisko), okoliczności (popłoch, ucieczka i postrzelenie) i współuczestniczenia widza $\mathrm{w}$ niemającym końca, długim umieraniu śmiertelnie rannego w brzuch Maćka.

Warto też dodać, iż wykorzystane w Popiele $i$ diamencie rozwiązania inscenizacyjne, twórczo organizujące współudział aktorów, pojawiają się u Wajdy nie po raz pierwszy. Zalążek tej latami rozwijanej przez niego synergicznej metody pracy $\mathrm{z}$ aktorami zawiera już - niesłusznie zapomniana - kapitalna w swym zaimprowizowanym przebiegu króciutka scena gry przyjaciół (Łomnicki, Cybulski) w rzucanie nożem, czyli pikuty, w Pokoleniu (1954). Obraz ten, z pozoru epizodyczny w swej rodzajowości i niewnoszący niczego istotnego do samego filmu, łączy w jedno niezbędną umiejętność operowania nożem przez obu młodych aktorów z dezynwolturą i spontanicznością aktorskich zachowań.

\section{Z teatru na ekran}

W drugiej połowie lat pięćdziesiątych, po sukcesach Kanału oraz Popiołu $i$ diamentu, środowiskowa ranga młodego Wajdy jako wybitnego artysty kina urosła niepomiernie. Od tamtego czasu zagrać w jego filmie oznaczało dla aktora nie lada honor i nobilitację w zawodzie. Angażując wedle własnego uznania i impulsów płynących z reżyserskiej intuicji, wiele od angażowanych wymagał. Nie liczyła się skala granej roli, lecz osiągnięty wyraz. Dla swoich największych odkryć z wczesnego okresu: Cybulskiego i Kobieli (po fenomenalnym Drewnowskim u Wajdy patrz: Piszczyk w Zezowatym szczęściu Munka, 1960) nie miał jednak - może z wyjątkiem postaci urzędnika Zbyszka w warszawskiej noweli w Miłości dwudziestolatków - propozycji aktorskich odpowiednich do skali ich wielkich, a nie do końca wykorzystanych talentów.

Po Popiele $i$ diamencie jako reżyser zyskał niezmiernie cenną świadomość znaczenia aktora i aktorstwa dla filmu. Zdał sobie sprawę, że bez 
usilnej, odkrywczej pracy nad rolą i bez wydobycia z wykonawców maksimum umiejętności nie powstanie dzieło sztuki filmowej z prawdziwego zdarzenia. Kolejne filmy (Lotna, Niewinni czarodzieje, Samson, Bramy raju, Powiatowa lady Makbet) pod względem aktorskim jednak rozczarowują. Aktorstwo Popiołów także jest dość przeciętne - jakby rozmyte, mało konsekwentne i ginące w epickim żywiole. Nawet główna postać, Rafał Olbromski, w interpretacji młodziutkiego Daniela Olbrychskiego, poza powiewem młodości i brawurą aktorską nie wnosi do filmu niczego istotnego.

W tym właśnie czasie pojawia się słynne, tysiące razy potem cytowane zdanie, jakie pod adresem Wajdy miał wypowiedzieć na lotnisku w Rzymie Zbyszek Cybulski „Powiedzcie mu, że jeszcze za mną zatęskni”. Po raz ostatni obaj pracowali z sobą przy noweli warszawskiej w Miłości dwudziestolatków (1962). Potem nastąpiła długa, pięcioletnia przerwa. Wiele razy pisano o autotematycznych wątkach Wszystko na sprzedaż. Warto do nich dopisać po latach jeszcze jeden: filmowe wspomnienie tragicznie zmarłego Zbyszka wyzwala u Andrzeja reżyserskie marzenie i tęsknotę za utraconym bezpowrotnie spotkaniem $\mathrm{z}$ wielką osobowością aktorską, zdolną do tego, by nadać optymalny wyraz ekranowej wizji.

Ten szczególny i intymny rodzaj relacji, jaki Wajda nawiązywał ze „swoimi” aktorami, zakładał w jego przypadku współtwórczą bliskość i więź. Każdy indywidualnie traktowany wykonawca otrzymywał od niego swoją szansę: od ról głównych, poprzez drugoplanowe, aż do fenomenalnie nieraz opracowanych i zagranych epizodów. Przykładowo: Stanisław Milski, Barbara Krafftówna, Jan Ciecierski i Artur Młodnicki w Popiele i diamencie, Henryk Cudnowski w Lotnej, Maja Komorowska, Bożena Dykiel i Małgorzata Lorentowicz w Weselu, Wojciech Siemion i Franciszek Pieczka w Ziemi obiecanej, Janusz Gajos w Dyrygencie, Emilia Krakowska, Roman Wilhelmi i Jerzy Stuhr w Bez znieczulenia, Małgorzata Zajączkowska jako służąca Duplay i Angela Winkler jako Lucille Desmoulins w Dantonie, Krzysztof Kolberger (Adam Mickiewicz) i Krystyna Zachwatowicz (Kawiarka) w Panu Tadeuszu itd.

Rozdział ten otrzymał tytuł $Z$ teatru na ekran, ale w przypadku drogi twórczej Wajdy i uprawianego przezeń typu aktorstwa, jaki przez dziesiątki lat preferował, można by go z powodzeniem odwrócić. Nie teatr był bowiem w jego przypadku na początku, lecz film. Choć do teatru zawsze go ciągnęło. Pierwszy spektakl teatralny wyreżyserował już jako sławny reżyser filmowy. Mowa o Kapeluszu pelnym deszczu w Teatrze Wybrzeże (premiera 1 maja 1959); wkrótce potem dwie inne prace teatralne: najpierw Hamlet $\mathrm{z}$ Edmundem Fettingiem w roli tytułowej również w Teatrze Wybrzeże (13 sierpnia 1960), a następnie Dwoje na huśtawce 
z Elżbietą Kępińską i Zbigniewem Cybulskim w stołecznym Teatrze Ateneum na Scenie 61 (21 grudnia 1960).

W latach siedemdziesiątych twórczość reżyserska Andrzeja Wajdy osiągnęła kapitalną równowagę między jego poszukiwaniami teatralnymi a dokonaniami filmowymi. Jedno wydaje się wyrastać z drugiego, znajdując w nim kontrapunkt i alternatywną linię swego rozwoju. Przepływ między aktorstwem teatralnym a aktorstwem filmowym dokonuje się w twórczości Wajdy w obie strony. Pomysły i rozwiązania teatralne organicznie przechodzą w filmowe i vice versa. Różnica dzieląca dwa odmienne media - będąca zazwyczaj czymś nieokreślonym i zagadkowym, co zbija $\mathrm{z}$ tropu większość reżyserów - w jego przypadku wydaje się nie stanowić istotnego problemu.

Więcej jeszcze: w miarę zdobywania kolejnych doświadczeń Wajda zyskuje biegłość $\mathrm{w}$ swobodnym czerpaniu $\mathrm{z}$ teatralnego mainstreamu, który sam tworzy (Teatr Wybrzeże, Ateneum, Stary Teatr w Krakowie, Teatr Powszechny w Warszawie i inne sceny) na potrzeby kina. Wie bowiem, że realizacja filmu daje reżyserowi nieosiągalną w żadnym etatowym teatrze szansę i możliwość wykreowania optymalnie wyszukanej obsady obsad - najlepszej z możliwych - w kraju, a nawet poza granicami. To przypadek między innymi: Popiołu i diamentu, Wesela, Ziemi obiecanej, Dantona, Zemsty, Pana Tadeusza, Katynia.

Opisywana tutaj współzależność, widoczna w dokonaniach twórczych reżysera, może być eksplikowana zarówno genetycznie (poszczególne inscenizacje teatralne stają się z czasem dziełami filmowymi), jak i funkcjonalnie - na zasadzie intrygującej homologii struktur. Można tu wręcz mówić o serii autoadaptacji czerpanych z zasobów jego własnych wcześniejszych doświadczeń. Dotyczy to zwłaszcza Sprawy Dantona Stanisławy Przybyszewskiej. Znakomity film nakręcony w Paryżu w roku 1982 poprzedziły aż dwie inscenizacje teatralne: najpierw na deskach Teatru Powszechnego w Warszawie (premiera 25 stycznia 1975), a pięć lat później - na scenie gdańskiego Teatru Wybrzeże (premiera 9 listopada 1980). W przypadku wspomnianego filmu jego autor sięgnął po gwiezdne grono fantastycznych wykonawców, z których potrafił stworzyć rewelacyjny wprost zespół.

Z biegiem czasu Wajda stał się wyrafinowanym smakoszem obsady aktorskiej. Czołówki filmowe i napisy końcowe mówią same za siebie. Do swoich filmów wybierał i angażował najlepszych z najlepszych. Dość przypomnieć, że grali u niego: John Gielgud, Hanna Schygulla, Angela Winkler, Omar Sharif, Gérard Depardieu, Patrice Chéreau, Tadeusz Łomnicki, Tadeusz Janczar, Wieńczysław Gliński, Zbigniew Cybulski, Bogumił Kobiela, Aleksander Bardini, Małgorzata Braunek, Jan Krecz- 
mar, Andrzej Łapicki, Beata Tyszkiewicz, Stanisława Celińska, Tadeusz Białoszczyński, Zofia Jaroszewska, Elżbieta Czyżewska, Zbigniew Zapasiewicz, Jerzy Trela, Krystyna Janda, Andrzej Seweryn, Daniel Olbrychski, Wojciech Pszoniak, Olgierd Łukaszewicz, Roman Wilhelmi, Maja Komorowska, Anna Seniuk, Jerzy Stuhr, Jerzy Radziwiłowicz, Jan Nowicki, Marek Kondrat, Marek Walczewski, Bogusław Linda, Mirosław Baka, Krzysztof Kolberger, Danuta Stenka, Maja Ostaszewska, Jan Englert $\mathrm{i}$ in.

Bywało, że niektórzy - jak Olbrychski, Seweryn, Janda, Pszoniak czy Stuhr - występowali w jego filmach wielokrotnie. Nie znaczy to jednak, że wytworzył sobie stały zespół, coś w rodzaju własnej stajni aktorskiej. Nie potrzebował nigdy czegoś podobnego, dobrze wiedząc, że o trafności i nośności artystycznej obsady decyduje niczym nieograniczona, reżyserska swoboda w podejmowaniu decyzji. Bywało, że zmieniał ją nawet w trakcie zdjęć. Szczęśliwie zachował tę wolność wyboru obsady przez całą swoją reżyserską drogę, co sprawiało, że idąc na kolejny film Wajdy, zawsze można było się spodziewać jakiejś przynajmniej jednej aktorskiej rewelacji.

Da się zauważyć intrygującą ciągłość trwających na przestrzeni szeregu lat poszukiwań, dzięki której w pełni dojrzały już reżyser Andrzej Wajda stopniowo odkrywał nie tylko potencjał teatralny prozy Fiodora Dostojewskiego w związku z inscenizacją Biesów na scenie Starego Teatru w Krakowie (premiera 29 kwietnia 1971), ale także doniosłe znaczenie i prawdziwą wagę wielomiesięcznej intensywnej pracy ze swoimi aktorami nad spektaklem.

W opisywanym tu przypadku chodzi o okres sześciu lat, rozciągający się między Biesami (1971) a inscenizacją fragmentu Idioty, która pod tytułem Nastazja Filipowna została zaprezentowana publiczności na scenie Starego Teatru w roku 1977 (premiera 17 lutego 1977). Czas ten stanowi fenomenalnie bogate i obfitujące w liczne dzieła stadium rozwoju artystycznego reżysera. Nie chodzi tylko o jego kolejne dokonania teatralne w tamtej dekadzie (oprócz Biesów - Noc listopadowa, 1974, Sprawa Dantona dwukrotnie 1975 i 1980, Gdy rozum śpi..., 1976, Emigranci, 1976, Rozmowy z katem, 1977), lecz o kapitalne filmy, jakie wówczas nakręcił.

To w tamtym okresie powstały: Krajobraz po bitwie (1971), Piłat i inni, 1971, Wesele (1972), Ziemia obiecana (1974-1975) w wersji kinowej i telewizyjnej, Człowiek z marmuru (1976-1977), Bez znieczulenia (1978) i Panny $z$ Wilka (1979) - nie wspominając już o szeregu pomniejszych prac reżyserskich. Z punktu widzenia szerszej całości można tu mówić o nakładaniu się i charakterystycznej interferencji serii współ- 
bieżnych poszukiwań teatralnych i filmowych. Filmy wówczas przez niego zrealizowane „nakładają się" niejako na prace teatralne, stanowiąc w wielu aspektach ich artystyczne dopełnienie.

\section{Przypadek Nastazji Filipowny}

Twierdzę, że kolejny etap osobistej fascynacji Andrzeja Wajdy fenomenem aktora i aktorstwa przypada na okres w pełni dojrzałej jego twórczości reżyserskiej. Pewnym zaskoczeniem dla czytelnika może być to, iż początek tego stadium wiążę nie z którymś z jego sławnych dokonań filmowych, lecz z na ogół raczej pomijanym w omówieniach dorobku serialem telewizyjnym $Z$ biegiem lat, $z$ biegiem dni... Serialem i spektaklem - równocześnie. Serial ten, nakręcony w roku 1980 (osiem odcinków po około 80 minut każdy), poprzedziła bowiem pamiętna wielogodzinna inscenizacja na deskach Starego Teatru w Krakowie - ze znamiennym podtytułem Opowieść na jedna noc lub trzy wieczory (premiera 29, 30, 31 marca i 1 kwietnia 1978).

Czy w przywołanym serialu dają o sobie znać jakieś wybitne kreacje aktorskie? Wolno sądzić, że nie. Nie o to bowiem chodziło. W widowisku tym, podobnie jak na scenie, potrzebny był mu zespół, a nie konstelacja gwiazd. Pamiętając to wyjściowe założenie zarówno spektaklu, jak i serialu, warto zwrócić uwagę, iż zaprezentowane w nim aktorstwo w niezwykle umiejętny i sugestywny sposób łączy w sobie wieloletnie doświadczenie teatralne i filmowe Wajdy $\mathrm{z}$ aktorami. Wykorzystane jednak przez niego, zaaranżowane i, by tak rzec, przepracowane w szczególny sposób.

To aktorstwo rodem $\mathrm{z}$ teatru repertuarowego najwyższej klasy, skoncentrowane na wypróbowanych metodach i biegłości warsztatu aktorskiego, która pozwala nie tylko kreować postać, ale również wspólnie $\mathrm{z}$ widownią bawić się ( $\mathrm{w}$ tym znaczeniu zabawy, które ustanowił na kartach Homo ludens Johan Huizinga) kreowaną rolą. Zabawa w takim sensie przynależy w sposób organiczny do najszerzej pojętej kultury i może przybierać i osiągać dowolnie wyrafinowany kształt. Ów „zabawowy” efekt okazuje się możliwy do osiągnięcia tylko w przypadku wytrawnych, wszechstronnie przygotowanych do zawodu wykonawców.

Po latach pracy $\mathrm{z}$ wytrawnymi profesjonalistami i mistrzami swego zawodu, takimi jak: Anna Polony, Aleksander Bardini, Gustaw Holoubek, Jan Ciecierski, Stanisław Milski, Artur Młodnicki, Wiktor Sadecki, Jerzy Bińczycki, Teresa Budzisz-Krzyżanowska, Jerzy Trela, Jerzy Radziwiłowicz, Jerzy Stuhr, Krzysztof Globisz (albo po drugiej stronie Atlantyku młoda Meryl Streep jako Liza w reżyserowanej na scenie aka- 
demickiej Yale Repertory Theatre w New Haven, Connecticut, inscenizacji Biesów) - następuje w twórczości Andrzeja Wajdy dojrzała faza ponownego odkrycia warsztatowych podstaw sztuki aktorskiej. Podstaw, od których stroniło niegdyś, dufne we własne niezależne źródła ekspresji, "offowe” i „nowoczesne” aktorstwo filmowe lat pięćdziesiątych, jakiemu sam przez pewien czas hołdował.

Coraz mniej „offowych” eksperymentów, coraz więcej autorskiego przywiązania do rozmaitych przewag i możliwości, jakie ma do zaoferowania reżyserowi sprawdzone profesjonalne aktorstwo. Tak, w największym skrócie, można by przedstawić kierunek przemian w relacji Wajda - aktorzy, zachodzących w dojrzałym okresie jego twórczości reżyserskiej $\mathrm{w}$ teatrze i filmie.

$\mathrm{Na}$ przełomie lat osiemdziesiątych i dziewięćdziesiątych podczas dłuższego pobytu w Japonii zetknął się Wajda z Tamasaburo Bando najwyższej klasy aktorem teatralnym, wyspecjalizowanym w graniu ról kobiecych. W efekcie tego spotkania dokonało się ponowne odkrycie przez reżysera doniosłości doprowadzonego do absolutnej maestrii rzemiosła aktorskiego. Kunszt aktorski Bando zafascynował Wajdę. Pisał na jego temat następująco:

\begin{abstract}
Kobieta wkraczająca na scenę wie, że jest kobietą, w związku z tym jej zadaniem jest stworzyć charakter Julii czy Lady Makbet, ale kobietą już jest. Natomiast mężczyzna, taki właśnie jak Tamasaburo Bando, wkraczając na scenę, musi stworzyć nie tylko osobowość, ale kobietę jako taką. Kobiecy głos, kobiecy krok, sposób zakładania szala, sposób przypinania kolczyków. Wszystko to są rzeczy wystudiowane z tysięcy możliwości, zostaje ta jedna, o której wie, że w tym momencie jest to jedyny gest, ten jedyny ton głosu, który właśnie ta kobieta potrafi z siebie wydobyć, i to jest właśnie kreacja. Na tym polega sztuka! Najbardziej zachwyca, że to jest sztuczne, że jest w tym istota teatru, czyli dążenie do tego, by stworzyć sztukę ze sztuczności. On właśnie jest tego największym na świecie uosobieniem ${ }^{6}$.
\end{abstract}

Słowa te opisują pełne podziwu wrażenie widza spektaklu teatralnego, ale nic nie stoi na przeszkodzie, by odnieść je również do magii aktorstwa, jaką zaprezentował Tamasaburo Bando w nakręconym przez Andrzeja Wajdę filmie Nastazja. Zachwyt ten i sam film zrodził się z fascynacji unikatowym kunsztem aktorskim i z pragnienia, by owo mistrzostwo wyprowadzić na moment $\mathrm{z}$ przestrzeni teatru $\mathrm{i}$ - nadając mu nieco odmienny nowy kształt i wyraz - uwiecznić na taśmie filmowej.

6 Wypowiedź Andrzeja Wajdy. Cytat ze ścieżki dźwiękowej filmu dokumentalnego Ireneusza Englera Kreacje Tamasaburo Bando. Prod. TVP 1991. 
Zakładam, że ten antropologiczny czy też antropokulturowy aspekt sfilmowanego fenomenu sztuki aktorskiej w odniesieniu do niektórych przynajmniej dzieł Wajdy zasługuje i zasługiwać będzie w przyszłości na dużo uważniejsze i bardziej pogłębione rozpatrzenie.

\section{Konkluzja}

Szkic niniejszy bynajmniej nie pretenduje do rangi rozwiniętego studium badawczego zdolnego wyczerpać - jeśli nie pod względem materiałowym, to przynajmniej problemowym - złożone zagadnienie aktora i aktorstwa w filmach Andrzeja Wajdy. Synteza taka zapewne kiedyś powstanie, ale z pewnością jej opracowanie i napisanie nie będzie zadaniem łatwym. Cel, jaki przed sobą postawiliśmy, był o wiele skromniejszy: zwrócić uwagę na niektóre przynajmniej - uznane tutaj za istotne - kwestie dotyczace fenomenu poetyki aktorstwa w filmach Wajdy. Kwestie, bez uwzględnienia których fenomen ten nie mógłby w praktyce reżyserskiej i inscenizacyjnej realnie zaistnieć.

Wajda jako reżyser filmowy - przy wszystkich jego kreacyjnych dążeniach czy, jak kto woli, inklinacjach do kreowania czegoś w rodzaju panopticonu historycznego polskości - ze wszech miar zasługuje na to, by dostrzec i wnikliwie zbadać udział sztuki aktorskiej w nakręconych przez niego ponad czterdziestu filmach. Nie stworzył nigdy osobnej "szkoły” aktorstwa filmowego, niemniej wniósł do jego rodzimego i światowego dorobku ogromny wkład twórczy, na który składają się dziesiątki, jeśli nie setki, niezapomnianych kreacji aktorskich.

\section{BIBLIOGRAFIA}

Dostojewski - teatr sumienia. Trzy inscenizacje Andrzeja Wajdy, oprac. M. Karpiński, Warszawa 1989.

Janicki S., Polscy twórcy filmowi o sobie, wstęp K. Eberhardt, Warszawa 1962.

Karpiński M., Teatr Andrzeja Wajdy, Warszawa 1991.

Michalak B., Wajda. Kronika wypadków filmowych, Warszawa 2016.

Michałek B., Polska przygoda neorealizmu, [w:] B. Michałek, Ćwiczenia z anatomii kina, Warszawa 1976.

Wajda A., Fenomen Cybulskiego, [w:] W. Zdort, Cybulski na planie „Popiołu i diamentu”, Łódź 1997.

Wajda mówi o sobie, wstęp, wybór i oprac. W. Wertenstein, Kraków 1991.

Walaszek J., Dwie „Nastazje” Andrzeja Wajdy, „Polska Sztuka Ludowa - Konteksty” 1993, nr 2.

Zdort W., Cybulski na planie filmu „Popiót i diament”, Łódź 1997. 